\title{
Parental knowledge and attitudes regarding the emergency treatment of avulsed permanent teeth
}

\author{
Sezin Ozer ${ }^{1}$ \\ Elif Ipek Yilmaz' \\ Sule Bayrak ${ }^{1}$ \\ Emine Sen Tunc ${ }^{1}$
}

\section{ABSTRACT}

Objective: The aim of this study was to examine parental knowledge and attitudes about avulsed permanent teeth and their emergency treatment in children.

Methods: A total of 289 parents of children aged 6-12 years receiving care at the Ondokuz Mayis University Pediatric Dentistry Clinic were included in the study. Questionnaires were used to collect data on parents' demographic characteristics, previous training in traumatic dental injury and treatment and knowledge of avulsed permanent teeth and their emergency management. Chi-square tests were used to identify differences in responses for different variables.

Results: More than half of the participating parents were female $(69.6 \%)$ and between the age of 30-39 years (64.4\%). Most (90.7\%) reported that they would not replant the avulsed tooth in its socket, and most (68.2\%) gave correct answers regarding the optimum time for which an avulsed tooth should be left out of the mouth prior to replantation. However, most parents were not sufficiently informed about the appropriate method for cleaning a dirty avulsed tooth or transporting it to a dentist or doctor. None of the demographic characteristics or training status was found to have a statistically significant effect on the number of correct responses regarding appropriate management of avulsion injuries $(P>$.05)

Conclusion: This study revealed that the parental level of knowledge about the emergency treatment of avulsion in children is inadequate and that educational campaigns are necessary to improve proper emergency management of dental avulsion. (Eur J Dent 2012;6:370-375)

Key words: Avulsion; children; parent; pediatric dentistry

1 Department of Pediatric Dentistry, Faculty of Dentistry, Ondokuz Mayis University, Samsun, TURKIYE

Corresponding author: Dr. Sezin Ozer Ondokuz Mayis Universitesi, Dishekimligi Fakultesi, Cocuk Dishekimligi A.D.

55139, Atakum, Samsun, TURKIYE

Tel: +903623121919 int 3679

Fax: +903624576032

Email: sezinsezgin78dyahoo.com

\section{INTRODUCTION}

Traumatic dentoalveolar injuries occur frequently in children and adolescents, affecting teeth, their supporting structures and adjacent soft tissues and contributing to major psychosocial and economic problems. Various studies conducted among different populations have reported prevalence rates for traumatic dental injuries to 
be between $4.9 \%-37 \% .^{2-7}$ One of the most serious traumatic dental injuries is avulsion, in which one or more teeth are completely knocked out of their alveolar sockets. ${ }^{8}$ Avulsions constitute $0.5 \%-16 \%$ of all traumatic dental injuries to permanent anterior teeth $^{9-10}$ and most often involves the maxillary central incisor. ${ }^{11}$ Although avulsion may occur at any age, the most common age for avulsion of permanent dentition is between 8-12 years of age, a time when the loosely structured periodontal ligament surrounding erupting teeth provides only minimal resistance to an extrusive force. ${ }^{8}$

Prompt and appropriate emergency management is exceedingly important for the best longterm prognosis of teeth affected by avulsion, especially in young children. ${ }^{12}$ Ideally, an avulsed tooth should be immediately replanted in its socket in order to avoid further damage to the periodontal membrane. ${ }^{8}$ The prognosis of a replanted tooth depends on the period of time elapsed between trauma and replantation, the type and condition of storage medium, the stage of root formation and the presence of contamination. ${ }^{1}$ Therefore, it is essential that the lay population, including parents, caretakers and teachers, who are among those most often present when an injury occurs, are aware of the appropriate methods for managing avulsion. ${ }^{13}$

Although numerous studies have been conducted in different countries to evaluate parental knowledge and attitudes regarding avulsed permanent teeth, 1,12,15,16 to the best of our knowledge, few studies have been conducted among Turkish parents. ${ }^{17}$ Therefore, this study aimed to investigate parental knowledge and attitudes regarding avulsed permanent teeth and their emergency treatment in children in Samsun, Turkey.

\section{MATERIALS AND METHODS}

A total of 289 parents of children aged 6-12 years receiving care at the Ondokuz Mayis University Pediatric Dentistry Clinic were included in the study.

Participation in the study was voluntary and completely confidential. The study instrument consisted of a questionnaire that was implemented anonymously among parents. The questionnaire was designed to collect data on demographic characteristics lage, sex, educational level and number of children); previous training in trau- matic dental injury and treatment; and knowledge of avulsed permanent teeth and their immediate emergency management.

Data collected from the questionnaires was coded and statistical analysis performed using the software SPSS version 13.0 for Windows ISPSS Inc., Chicago, IL, USA). Chi-square tests were used to identify differences in responses for different variables, with the level of significance set at $P=.05$.

\section{RESULTS}

Demographic characteristics of respondents are given in Table 1. More than half of participating parents $(69.6 \%, n=201)$ were female and between age 30-39 years $(64.4 \%, n=186)$. All respondents had at least one child between the ages of 6-12 years.

Responses to questions related to parents' perceived knowledge and attitudes regarding traumatic dental injuries are given in Table 2. Most parents (74.7\%; $n=216$ ) reported that they had never received any information about traumatic dental injuries, although $19 \%(n=55)$ of parents had obtained knowledge about traumatic dental injuries from a dentist. While the majority of parents (78.2\%, $n=226)$ felt they had inadequate information about traumatic dental injuries, $59.5 \%(n=172)$ of the respondents said having information about traumatic dental injuries was very important.

Responses to questions related to specific knowledge of emergency management of avulsed tooth injuries are given in Table 3 . The vast majority $90.7 \%(n=262)$ of the respondents reported that they would not replant an avulsed tooth in its socket. When asked what type of media was best for storing an avulsed tooth until a dental professional could be reached, only $9 \%(n=26)$ chose physiological media (sterile saline, milk, saliva), whereas $67.1 \%(n=194)$ chose non-physiological media (tap water, ice storage, alcohol, dry storage) and the remaining $23.9 \%(n=69)$ of respondents said they did not know which storage media was best. Only $5.9 \%(n=17)$ of respondents were able to identify the correct procedure for cleaning an avulsed tooth, whereas $71.6 \%$ ( $n=207)$ were unable to provide any answer regarding how to clean an avulsed tooth. When asked where they would take their children in the event of a traumatic dental injury, $46.0 \%(n=133)$ said the faculty of dentistry. 
Moreover, most parents (68.2\%, $n=197)$ knew the optimal length of time within which to seek professional help for an avulsed tooth. No statistically significant differences were found in the number of correct responses by age, sex, level of educational or number of children.

Table 1. Demographic characteristics of parents.

\begin{tabular}{|c|c|c|}
\hline Question & $\mathrm{n}$ & $\%$ \\
\hline \multicolumn{3}{|l|}{ Sex } \\
\hline Male & 88 & 30,4 \\
\hline Female & 201 & 69,6 \\
\hline \multicolumn{3}{|l|}{ Age } \\
\hline Under 20 years & 1 & 0,3 \\
\hline $20-29$ years & 30 & 10,4 \\
\hline $30-39$ years & 186 & 64,4 \\
\hline 40-49 years & 63 & 21,8 \\
\hline 50 years or older & 9 & 3,1 \\
\hline \multicolumn{3}{|l|}{ Education } \\
\hline None/Primary school & 156 & 54 \\
\hline High school and above & 133 & 46 \\
\hline \multicolumn{3}{|l|}{ Number of children } \\
\hline 1 & 33 & 11,4 \\
\hline 2 & 174 & 60,2 \\
\hline 3 & 65 & 22,5 \\
\hline$>3$ & 17 & 5,9 \\
\hline
\end{tabular}

Table 2. Parents' perceived knowledge and attitudes regarding traumatic dental injuries.

\begin{tabular}{|c|c|c|}
\hline Question & $\mathrm{n}$ & $\%$ \\
\hline \multicolumn{3}{|c|}{ Have you ever received any information regarding traumatic dental injuries } \\
\hline Yes & 106 & 36,6 \\
\hline No & 183 & 63,4 \\
\hline \multicolumn{3}{|c|}{ If yes, your primary source of TDI information was: } \\
\hline First aid course & 5 & 1,7 \\
\hline Dentist & 55 & 19 \\
\hline Family physician & 10 & 3,5 \\
\hline Other health specialist & 9 & 3,1 \\
\hline Friend & 8 & 2,8 \\
\hline Internet & 13 & 4,5 \\
\hline Other & 6 & 2,1 \\
\hline \multicolumn{3}{|c|}{ What is your level of information about traumatic dental injuries? } \\
\hline Adequate & 24 & 8,3 \\
\hline Inadequate & 226 & 78,2 \\
\hline Don't know & 39 & 13,5 \\
\hline \multicolumn{3}{|c|}{ Learning about traumatic dental injuries is: } \\
\hline Not important & 1 & 0,3 \\
\hline Important & 63 & 21,8 \\
\hline Somewhat important & 53 & 18,3 \\
\hline Very important & 172 & 59,5 \\
\hline \multicolumn{3}{|c|}{ Would you like to receive more information in order to properly manage traumatic dental injuries? } \\
\hline Yes & 279 & 96,5 \\
\hline No & 10 & 3,5 \\
\hline
\end{tabular}

European Journal of Dentistry 


\section{DISCUSSION}

The prognosis for avulsed teeth is improved by prompt and appropriate treatment, which often depends upon the knowledge of non-professionals present at the site of an accident before professional dental care can be provided. ${ }^{8}$ Given the many incidents that occur at home and school, parents and schoolteachers present in an emergency situation are fundamental to the provision of appropriate care to the injured child. ${ }^{18}$ Although numerous studies have been conducted in various countries examining the knowledge levels of parents, caretakers, teachers and other school personnel (nurses, coaches, etc.) regarding correct emergency treatment of tooth avulsion, 1,12,15,16,19-21 very few studies in Turkey have examined parental knowledge of the subject. Therefore, this study aimed to assess the knowledge and attitudes of Turkish parents regarding the emergency man- agement of avulsed permanent teeth in children.

In line with the findings of similar studies conducted in Nigeria ${ }^{20}$ and Singapore, ${ }^{19}$ the present study found parents have a low level of knowledge regarding the emergency treatment of tooth avulsion. This can be explained by the fact that most parents had not received any information about traumatic dental injuries. In one positive finding, parents indicated they were unsatisfied with their level of knowledge of dental trauma management and were interested in learning more.

Given that a lack of knowledge about emergency management procedures for avulsed teeth may severely affect the prognosis of an avulsed tooth, there is a clear need for educational campaigns to broaden the lay publics' knowledge of emergency management procedures for avulsed teeth. As Table 3 shows, very few respondents (9.3\%) said they would replant an avulsed tooth in the alveolar

Table 3. Parents' knowledge regarding the immediate emergency management of avulsed permanent teeth.

\begin{tabular}{|c|c|c|}
\hline Question & $\mathrm{n}$ & $\%$ \\
\hline \multicolumn{3}{|l|}{ Would you replant an avulsed tooth in its socket? } \\
\hline Yes & 27 & 9,3 \\
\hline No & 262 & 90,7 \\
\hline \multicolumn{3}{|c|}{ How do you clean a dirty avulsed tooth prior to replantation? } \\
\hline Brush the tooth & 63 & 21,8 \\
\hline Wash it under tap water & 17 & 5,9 \\
\hline Replace it in the alveolar socket or doing nothing & 2 & 0,7 \\
\hline Don't know/other & 207 & 71,6 \\
\hline \multicolumn{3}{|c|}{ Where would you take a child immediately after a dental avulsion? } \\
\hline Dental office & 22 & 7,6 \\
\hline Dental hospital & 125 & 43,3 \\
\hline Faculty of Dentistry & 133 & 46 \\
\hline Other & 9 & 3,1 \\
\hline \multicolumn{3}{|c|}{ When do you think is the best moment to look for professional help? } \\
\hline Within 30 minutes after avulsion & 197 & 68,2 \\
\hline Within 30-60 minutes after avulsion & 43 & 14,9 \\
\hline Within 1-2 hours after avulsion & 22 & 7,6 \\
\hline After a day(s) when the child felt better & 15 & 5,2 \\
\hline Don't know & 12 & 4,2 \\
\hline \multicolumn{3}{|c|}{ What is the best storage media for an avulsed tooth prior to seeing a dentist? } \\
\hline Tap water & 39 & 13,5 \\
\hline Ice & 77 & 26,6 \\
\hline Alcohol & 11 & 3,8 \\
\hline Sterile saline & 17 & 5,9 \\
\hline Milk & 5 & 1,7 \\
\hline Saliva & 4 & 1,4 \\
\hline Dry storage & 67 & 23,2 \\
\hline Don't know & 69 & 23,9 \\
\hline
\end{tabular}


socket, which is in line with previous studies. ${ }^{20,21}$ Few parents were able to identify the appropriate method for cleaning a dirty avulsed tooth prior to replantation, which is also in line with earlier studies. ${ }^{1,22}$ In the present study, nearly one-quarter of respondents stated that they would scrub a dirty avulsed tooth before replanting it in its socket, which, in fact, is known to severely decrease the chance of successful replantation.

Despite the anxiety involved in seeking emergency care for an injured child, nearly half of the respondents stated that they would bring their child to the Faculty of Dentistry following a traumatic dental injury. This may be explained by parents' perceptions that an academic setting will provide more highly trained professional staff and more advanced technology than other types of facilities, ${ }^{1}$ which reflects two basic assumptions, namely, that the faculty of dentistry is prepared to handle this type of patient, and that a specialist will provide better care than a general dentist. ${ }^{23}$

Studies of clinical outcomes of avulsed teeth have demonstrated that the longer the length of time elapsed between tooth avulsion and replantation, the greater the risk of replacement resorption and inflammatory root resorption. ${ }^{22}$ Whereas appropriate replantation of an avulsed permanent tooth within $30 \mathrm{~min}$ has been shown to have a $90 \%$ chance of success, ${ }^{24}$ only a negligible chance (5\%) of long-term retention of an avulsed tooth exists if replantation occurs after $2 \mathrm{~h} .{ }^{24}$ It is encouraging to note that $68.2 \%(n=197)$ of the respondents knew that for optimal healing, professional help should be sought within $30 \mathrm{~min}$. of a traumatic incident. Parental knowledge on this subject is comparable to that reported previously by Zhao and Gong. ${ }^{25}$

The ideal storage medium should be capable of preserving cell vitality, adherence and clonogenic capacity $^{26}$ and should be readily available at the site of the accident or easily accessible. ${ }^{27}$ If the tooth is transferred to a liquid medium such as the patient's own saliva, milk or saline within the first 15 minutes following avulsion, it is likely that some of the cells in the periodontal ligament and cementum will survive and play a role in regeneration. ${ }^{28}$ In the present study, rather than physiological media, most respondents believed tap water, ice, alcohol, or dry storage to be the best storage medium, and only a few were able to correctly identify sterile saline, milk, or saliva as the best storage medium.
Regardless of the age, education level or other factors, parental knowledge of tooth avulsion management was found to be low. While the important epidemiologic findings from this study may serve as a warning, they also represent a useful source of information for the support of education and prevention strategies and reduction of the overall cost of emergency and rehabilitative treatment.

\section{CONCLUSION}

Considering that many traumatic dental injuries occur at home and at school, the participation of parents and schoolteachers in the emergency situation is fundamental to providing appropriate care to the injured child. Within the limitations of the present study, parents were found to have a low level of knowledge regarding procedures to follow in an emergency related to tooth avulsion and replantation. Knowledge of emergency treatment of avulsed teeth should be increased by providing educational and preventive programs.

\section{REFERENCES}

1. Santos ME, Habecost AP, Gomes FV, Weber JB, de Oliveira MG. Parent and caretaker knowledge about avulsion of permanent teeth. Dent Traumatol 2009;25:203-208.

2. Schatz JP, Joho JP. A retrospective study of dento-alveolar injuries. Endod Dent Traumatol 1994;10:11-14.

3. Wilson S, Smith GA, Preisch J, Casamassimo PS. Epidemiology of dental trauma treated in an urban emergency department. Pediatr Emerg Care 1997;3:12-15.

4. Marcenes W, Al Beiruti N, Tayfour D, Issa S. Epidemiology of traumatic injuries to the permanent incisors of 9-12-yearold school children in Damascus, Syria. Endod Dent Traumatol 1999; 15:117-123.

5. Traebert J, Peres MA, Blank V, Böell RS, Pietruza JA. Prevalence of traumatic dental injury and associated factors among 12-year-old school children in Florianopolis, Brazil. Dent Traumatol 2003;19:15-18.

6. Rajab LD. Traumatic dental injuries in children presenting for treatment at the Department of Pediatric Dentistry, University of Jordan, 1997-2000. Dent Traumatol 2003;19:6-11.

7. Eyuboglu O, Yılmaz Y, Zehir C, Sahin H. A 6-year investigation into types of dental trauma treated in a paediatric dentistry clinic in Eastern Anatolia Region, Turkey. Dent Traumatol 2009;25:110-114.

8. Andreasen JO, Andreasen FM. Textbook and Color Atlas of Traumatic Injuries to the Teeth, $4^{\text {th }}$ ed. Oxford: Blackwell Publishing, 2007:444-480. 
9. Lygidakis NA, Marinou D, Katsaris N. Analysis of dental emergencies presenting to a community paediatric dentistry centre. Int J Paediatr Dent 1998;8:181-190.

10. Saroglu I, Sonmez H. The prevalence of traumatic injuries treated in the pedodontic clinic of Ankara University, Turkey, during 18 months. Dent Traumatol 2002;18:299-303.

11. Petrovic B, Marković D, Peric T, Blagojevic D. Factors related to treatment and outcomes of avulsed teeth. Dent Traumatol 2010;26:52-59.

12. Al-Jundi SH, Al-Waeili H, Khairalah K. Knowledge and attitude of Jordanian School health teachers with regards to emergency management of dental trauma. Dent Traumatol 2005;21:183-187.

13. Kinoshita S, Kojima R, Taguchi Y, Noda T. Tooth replantation after traumatic avulsion: a report of 10 cases. Dent Traumatol 2002;18:153-156.

14. Caglar E, Ferreira LP, Kargul B. Dental trauma management knowledge among a group of teachers in two south European cities. Dent Traumatol 2005;21:258-262.

15. Qazi SR, Nasir KS. First-aid knowledge about tooth avulsion among dentists, doctors and lay people. Dent Traumatol 2009;25:295-299.

16. Traebert J, Traiano ML, Armênio R, Barbieri DB, de Lacerda JT, Marcenes W. Knowledge of lay people and dentists in emergency management of dental trauma. Dent Traumatol 2009;25:277-283

17. Tozoglu U, Sahın H. Determination of the parents knowledge about dental avulsions and its treatments. Ataturk Univ Dis Hek Fak Derg 2006;16:19-22.

18. Pacheco LF, Filho PF, Letra A, Menezes R, Villoria GE, Ferreira SM. Evaluation of the knowledge of the treatment of avulsions in elementary school teachers in Rio de Janeiro, Brazil. Dent Traumatol 2003;19: 6-78.

19. Sae-Lim V, Chulaluk K, Lim LP. Patient and parental awareness of the importance of immediate management of traumatized teeth. Endod Dent Traumatol 1999;15:37-41.

20. Sanu 00, Utomi IL. Parenteral awareness of emergency management of avulsion of permanent teeth of children in Lagos, Nigeria. Niger Postgrad Med J 2005;12:115-120.

21. Andersson L, Al-Asfour A, Al-Jane Q. Knowledge of firstaid measures of avulsion and replantation of teeth: an interview of 221 Kuwaiti schoolchildren. Dent Traumatol 2006;22:57-65.

22. Al-Jame Q, Andersson L, Al-Asfour. Kuwaiti parents' knowledge of first-aid measures of avulsion and replantation of teeth. Med Princ Pract 2007;16:274-279.

23. Hu LW, Prisco CRD, Bombana AC. Knowledge of Brazilian general dentists and endodontists about the emergency management of dento-alveolar trauma. Dent Traumatol 2006;22:113-117
24. Lin S, Emodi O, El-Naaj IA. Splinting of an injured tooth as part of emergency treatment. Dent Traumol 2008;24:370372.

25. Andreasen JO, Hjorting-Hansen E. Replantation of teeth. I. Radiographic and clinical study of 110 human teeth replanted after accidental loss. Acta Odontol Scand 1966;24:263286.

26. Zhao Y, Gong Y. Knowledge of emergency management of avulsed teeth: a survey of dentists in Beijing, China. Dent Traumatol 2010;26:281-284.

27. Ashkenazi M, Marouni M, Sarnat H. In vitro viability, mitogenicity and clonogenic capacity of periodontal ligament cells after storage in four media at room temperature. Endod Dent Traumatol 2000;16:63-70.

28. Huang SC, Remeikis NA, Daniel JC. Effects of long-term exposure of human periodontal ligament cells milk and other solutions. J Endod 1996;22:30-33.

29. Donaldson M, Kinirons MJ. Factors affecting the time of onset of resorption in avulsed and replanted incisor teeth in children. Dent Traumatol 2001;17:205-209. 